\title{
The Analysis of Rural Communities Empowerment through the Establishment of BUMDes Based on Creative Economy to Increase Optimization of Village Funds
}

\author{
Agung Minto Wahyu ${ }^{1 *}$, Ega Aditya ${ }^{2}$, Navilah Laila Wardani ${ }^{3}$, Jeni Susyanti ${ }^{4}$ \\ 1,2,3,4 University of Islam Malang \\ *Corresponding author.Email: agungminto98@gmail.com
}

\begin{abstract}
The aim of this research is to analyze the empowerment of rural communities through the establishment of BUMDes based on creative economy; to analyze the optimization of village funds. This study uses qualitative methods with a case study approach. The case study was conducted at BUMDes Barokah in Putukrejo Village, Gondanglegi, Malang Regency. The findings of the study show that the establishment of BUMDes based on effective creative economy was carried out to empower rural communities. Furthermore, the empowerment of rural communities might increase community income to optimize village funds.
\end{abstract}

Keywords: community empowerment, BUMDes, creative economy, village funds

\section{INTRODUCTION}

Since the enactment of the Law No. 6 of the 2014 constitution concerning villages, the recognition of village autonomy has become increasingly concrete. These efforts are not impossible to actualize. Based on the Law No. 15 of the 2017 constitution towards the State Budget in 2018, village funds for the 2018 budget amounting to IDR 60 trillion have been allocated to all villages in Indonesia. With this amount, each village has the opportunity to get around IDR 800 million.

In its use, village funds have several priorities listed in Ministerial Regulation article 4 of the 2018 constitution number 16 , the use of village funds is prioritized to finance the implementation of programs and activities in the field of village development and empowerment of rural communities. It is expected that the program can provide the greatest benefit to the rural community in the form of improving quality of life, increasing welfare and alleviating poverty.

The efforts in empowering rural communities in real can be done through the establishment of Village-Owned Enterprises (Badan Usaha Milik Desa/BUMDes) as a part of priority of the use of village funds. The establishment of BUMDes is based on article 213 paragraph (1) No. 32 of the 2014 constitution towards Regional Government which states that villages can establish village-owned business entities in accordance with the needs and capability of the village. Even regulation of the village minister No. 4 of 2015 explains in more detail about the process of establishing BUMDes, managers of BUMDes, capital of BUMDes, types of businesses that are permitted, up to reporting and accountability for the BUMDes' report .Certainly, it brings a breath of fresh air to villages that have owned BUMDes but still do not really understand the correct management of BUMDes.

The purpose of the establishment of BUMDes is regulated in article 3 Permendesa No. 4 of 2015 , which is to improve the village economy, optimize village assets to be beneficial for village welfare, improve community efforts in managing village economic potential, open employment opportunities, and increase rural communities income and also original income to the village itself. Therefore, the establishment of BUMDes becomes an urgent matter to provide benefits for the village communities.

The Village Community Empowerment Office (Dinas Pemberdayaan Masyarakat dan Desa/DPMD) data states that there are 236 BUMDes until mid-2019 in Malang Regency. From this amount, there is a BUMDes which can be said to be one of the successful BUMDes in Malang Regency, BUMDes Barokah owned by Putukrejo Village, Gondanglegi, Malang Regency. 
Recently, BUMDes Barokah has four business units, they are Water and Sanitation Management Unit, Sumber Sira Tourism Unit, Savings and Loan Business, Production, Creativity and Services Unit, and Agriculture and Fisheries Unit.

In its development, currently BUMDes Barokah has developed its business unit by expanding into the creative economy sector. This was marked by the establishment of the Sumber Sira Tourism Village Market which was integrated with the Sumber Sira Tourism Unit. According to the Chairman of BUMDes Barokah, the Tourism Village Market owned by BUMDes Barokah is the only one in Malang Regency. BUMDes barokah managers see that the creative economy sector has a great potential to be developed through BUMDes. Creative economy shows a human action in terms of creating something new that has economic value. It is very possible to do by rural community [1].

Creative economy itself has 16 sub-sectors that get serious attention from the Creative Economy Agency (BEKRAF) [1] .BUMDes managers only need to adjust between the potential of the village and the 16 existing sub-sectors in exploring the creative economy sector. For example BUMDes Barokah which focuses on craft, fashion and culinary sub-sectors to be developed through the Sumber Sira Tourism Village Market.

From the success of BUMDes Barokah Putukrejo Village in empowering the community, especially as one of the pioneers in managing the BUMDes based on the creative economy, researcher was interested in conducting a case study in BUMDes Barokah.

The research method used is a qualitative research method. This type of qualitative research is carried out using case studies. In this study, data collection was carried out through observation and semi-structured interviews. Data collected were analyzed using data reduction, data presentation, and the results of research conclusions [2]. The results of the study are expected to be a reference for other village governments who want to establish BUMDes based on creative economies such as BUMDes Barokah.

The question of the study that become the purpose of this research is how the form of community empowerment is based on creative economy that can optimize village funds on the Barokah BUMDes.

\section{LITERATURE REVIEW}

Based on the introduction that has been presented previously, the following are the results of the study that can be a reference in conducting this research. This theory review consists of four theories, that is community empowerment, BUMDes, creative economy, and village funds.

\subsection{Community Empowerment}

Community empowerment is an economic development concept that summarizes social values. This concept reflects the new development paradigm that is people-centered, participatory, empowering, and sustainable [3]. According to Rapp port [4], empowerment is considered as a collaborative process in which people who are powerless towards valuable resources are mobilized to increase access and control over resources to solve personal and community problems. In contrast, according to Law No. 6 of the 2014 constitution towards Villages, empowerment of village communities is an effort to develop community independence and welfare by increasing knowledge, attitudes, skills, behaviors, abilities, awareness, and utilizing resources through the establishment of policies, programs, activities, and mentoring in accordance with the essence of the problem and priority needs of the rural communities. The success of community empowerment can be seen from the empowerment of those who are concerned with economic ability, welfare access capabilities, also cultural and political abilities.

\subsection{Village-Owned Enterprises (BUMDes)}

According to Law No. 6 of the 2014 constitution concerning Villages, BUMDes are business entities who's entire or part of their capital is owned by the village through direct participation originating from village assets which are separated to manage assets, services and other businesses for welfare of the rural communities. In short, the definition of BUMDes is set in article 1 paragraph 6 No. 39 of the 2010 Minister of Home Affairs Regulation towards Village-Owned Enterprises states that BUMDes are village businesses formed / established by village governments whose capital ownership and management is carried out by village governments and rural communities.

BUMDes are built on initiatives (community initiation), and are based on fundamental cooperative, participatory and emancipator, with two underlying principles, specifically member base and self-help [5]. As an embodiment of village productive economic management, the establishment and management of BUMDes must be carried out in a participatory, cooperative, accountable, transparent, sustainable and emancipator manner. Therefore, management of the business entity must be taken seriously so that it can run effectively, efficiently, professionally, independently to improve the welfare of the village community. In addition, the ability of the village apparatus to prepare personal capabilities and search for potential financial resources will greatly affect the readiness of the village government [6].

In an effort to achieve the goals of BUMDes, the community and the Village Government as managers can fulfil the (productive and consumptive) needs of the 
community through services in the distribution of goods and services. According to Law No. 6 of the 2014 constitution towards villages, the establishment of BUMDes must be carried out according to the needs and potential of the village. BUMDes management must also be carried out with a proper concept, including the transparency to the community, accountability in accordance with the rules and applicable law, the community must be actively involved in BUMDes. Despite, BUMDes must provide benefits to the community [7].

\subsection{Creative Economy}

Creative economy as an economic concept that prioritizes information and creativity by relying on ideas and stock of knowledge from human resources in its economic activities [1]. According to the Ministry of Commerce of the Republic of Indonesia (2008), creative industries are defined as industries originating from the use of creativity, skills, individual talents to create prosperity and employment through the creation and utilization of the individual's creative power.

Creative economy itself has 16 sub-sectors developed in Indonesia. Based on that sub-sectors, there are some of them that have already been implemented at BUMDes Barokah. They are food, fashion and craft.

\subsection{Village Funds}

According to Law No. 6 of the 2014 constitution, village funds are funds originating from the state budget allocated to villages that are transferred through the district budget and used to finance government administration, implementation, development, community development, and community empowerment.

At the beginning of the enactment of article 6 of the 2014 constitution, the focus of the use of village funds was to build infrastructure in the village. However, as time goes by, according to the instructions of the Minister of Village, the Development of Disadvantaged Regions and Transmigration, Eko Putro Sandjojo hopes the priority of using village funds 2019 is more for economic empowerment such as manufacturing (BUMDes) [8]

\section{METHODS}

This study uses a qualitative method. According to Moleong [2], qualitative research is a scientific research that aims to understand a phenomenon or case about what is experienced by research subjects. The approach used in this study is a case study. Herdiansyah [9] states that a case study is a qualitative research model that is detailed about an individual or a particular social unit over a period of time. Furthermore, case studies is comprehensive, intense, detailed, profound, and more directed model as an effort to examine problems or phenomenon that is contemporary. In case study, the researcher intends to find the uniqueness of the case so that it focused the questions towards its process and cause. In addition, researchers can also write the followup questions that are focused on the issues of topic under the study.

The selected case study design is a collective case study conducted to draw conclusions or generalizations towards the phenomenon or population of these cases [2]. This case study focuses on a creative economy-based community empowerment program at BUMDes Barokah. The Research location is in Putukrejo Village, Gondanglegi, Malang Regency.

This study used 4 participants who were carried out with side snowball techniques. The snowball sampling technique is a method for identifying, selecting and taking samples in a network or continuous row of relationships [9].

Data collection is done by observation and semistructured interviews. The collected data is then analyzed by reducing data, presenting data, and inferring the results of the study [2]. Furthermore, the researchers will check the validity data by testing the credibility through triangulation.

\section{RESULTS AND DISCUSSION}

Based on the interviews results with some subjects in Putukrejo Village, the following results were obtained.

\subsection{The Overview of BUMDes Barokah at Putukrejo Village}

BUMDes Barokah is located in Putukrejo Village, Gondanglegi, Malang Regency. According to the Head of the Putukrejo Village, the establishment of the BUMDes Barokah was based on the mandate of article 6 of the 2014 constitution towards villages where it was expected that each village would establish BUMDes. Starting from the distribution of village funds in 2015, the Putukrejo Village Government inaugurated BUMDes Barokah on December [9]. The name Barokah is a special gift from the Head of Putukrejo Village with the philosophy that every activity carried out on these BUMDes will get a blessing for all parties.

The establishment of BUMDes Barokah began with the dissemination of information to all rural communities aimed to make them understand about BUMDes, including the purpose and benefits of establishing BUMDes . It might convince the public that BUMDes will give benefit to the village. After the dissemination, there was a meeting between Village Council (Badan Permusyawaratan Desa/BPD), Village Government, and 
representatives of the rural community. The most important stage in the meetings is to carry out the aspiration mapping according to community needs regarding BUMDes led by the BPD . From this stage, it could be identified the potentials in Putukrejo Village, the needs of the Putukrejo Village Residents, the design of business units, the organization structure of the BUMDes, the business capital of BUMDes, and the draft BUMDes Articles of Association and Bylaws After that, the last step was to establish the Putukrejo Village Regulation concerning the establishment of Barokah BUMDes.

Based on the village potential that has been discussed in the village meeting, currently BUMDes Barokah already has four operating business units, as follows.

\subsubsection{Sumber Sira Tourism Unit}

Sumber Sira Tourism Unit is one of the priority business units at Barokah BUMDes. Historically, this Sumber Sira Springs have been existing for several centuries. Therefore, it can be said that Sumber Sira already existed earlier than Barokah BUMDes. After BUMDes Barokah took over Sumber Sira, there are a lot of significant changes especially towards the development of supporting infrastructure around Sumber Sira Tourism Unit. It can be seen from the access road, UMKM trading stand, to the abundant instagramable photo spots.

Also, BUMDes Barokah promote the Sumber Sira Tourism Unit massively which has attractive water photo spots with beautiful algae views. In consideration of the efforts of BUMDes Barokah, many tourists were interested in enjoying the beauty of Sumber Sira Tourism. It also became a new economic resource for the Putukrejo Village Community and increased Village Original Income.

\subsubsection{Clean Water and Sanitation Facilities Management Unit}

The utilization of clean water facilities at Sumber Sira began in 2004. In consideration of the enthusiasm and mutual cooperation from the community together with the village government who dug a water pipe and installed a water pump to lift the water. It has become the forerunner of the water and sanitation facilities management unit at BUMDes Barokah. BUMDes Barokah, which has taken over management, also built a sanitation system to manage household waste, and created a good drainage system. Until now, this unit is able to serve ten villages in Gondanglegi and Bululawang district.

\subsubsection{Savings and Loans, Business, Production, Creativity and Services Unit}

This business unit is a combination of several business units which are relatively under development.
This merger was carried out to make more efficient organizational structure in this Unit.

The savings and loan unit focus on providing capital loans to the community. The capital loan is expected to be used by the community in establishing a culinary or fashion business around the Sumber Sira Tourism Unit.

Besides, it can be used to make some creative crafts. Then, the products might sell through the Sumber Sira Tourism Village Market. Therefore, this business unit will play an important role in driving the BUMDes Barokah based on a creative economy.

\subsubsection{Agriculture and Fisheries Unit}

The agricultural business unit is formed from the needs of the people who are members of farmer groups regarding the availability of fertilizer. From this background, an agricultural business unit which was initially focused on providing fertilizer stocks for the community who work as farmers was formed. As time goes by, the agricultural unit is capable of producing its own rice under the brand of Beras Berkah. The rice is obtained from harvests from the community itself which are processed and redistributed to meet the food needs of the Putukrejo Village Community.

Apart from agriculture, there is also fisheries in this business unit. Similar to agriculture, fisheries units try to provide fish feed for fish farming communities. In addition, this unit also provides socialization on how to raise fish properly so that they will increase the quality of the community's harvest.

\subsection{Community Empowerment through BUMDes based on Creative Economy}

The establishment of BUMDes as the beginning of real community empowerment was carried out in Putukrejo Village. The empowerment through these BUMDes is not only focused solely on economic empowerment, but also is expected to be able to empower people in politics and culture.

Economically, the community is able to utilize BUMDes as a place to improve its economic condition. While from a political standpoint, the community can convey all their aspirations regarding BUMDes in every village meeting. The involvement of the community which is very important is in the check and balance process regarding every policy implemented by the Putukrejo Village Government in the Barokah BUMDes. Besides, it is also expected to be able to maintain the village culture through mutual cooperation through BUMDes.

Empowerment in BUMDes is not only focused on the final results, but also to improve the capacity of human resources [10]. In this case, the community is involved in every decision making and places them in every 
BUMDes management. Thus, people can see the economic opportunities that exist in BUMDes easily. The hope is that people can create new businesses that can improve the welfare of their lives. As what Sumodiningrat [11] states that empowering the community requires a main approach, namely the effort must be directed, carried out by the target community, and using a group approach.

So far, community empowerment in BUMDes Barokah has been effective. This is directly proportional to the growing development of existing business units. For example, in the Sumber Sira Tourism Unit, in addition to increasing Village Original Income (Pendapatan Asli Desa/PADes), the surrounding community also becomes empowered by peddling in the Sumber Sira area. Seeing this potential, the manager of BUMDes Barokah then took the initiative to be more serious in taking the opportunity to empower the community.

The form of real implementation in answering these opportunities is by establishing the Sumber Sira Tourism Village Market. This tourist village market is a place to accommodate creative economic work from the community. Therefore, it is expected to provide an injection of enthusiasm for the community in making crafts through this tourist village market. It answers the community concern in marketing their craft by the existence of the tourist village market.

The opportunity for BUMDes to explore the creative economy in empowering the community is the right thing. However, not all sub-sectors in the creative economy can be directly applied. In BUMDes Barokah, this time there are three sub-sectors developed, culinary, fashion and craft sub-sectors. There are three sub-sectors in the development of the creative economy. However, the community needs to be given continuous debriefing on the manufacture of products and ways of good packaging. It can further increase its economic value.

Other potential sub-sectors to be developed is photography. Armed with captivating scenery and abundant photo spots in the Sumber Sira Tourism Unit, it can be made a new economic resource by providing photography services. Teenagers in Putukrejo Village who have the ability in the field of photography can be empowered in managing this business unit.

\subsection{The optimization of Village Funds through BUMDes}

Regarding the optimization of village funds, it is certainly very much influenced by the readiness of the village government. According to Hendri [12], the readiness of the village government is the ability of the village apparatus to prepare their personal abilities and the ability of the village apparatus to look for potential financial resources. Therefore, it can be said that the village government that is ready will be better to optimize village funds in increasing PADes.

Based on the Village Budget of Putukrejo in 2018, the following data were obtained.

Table 1. APBDes Desa Putukrejo 2018

\begin{tabular}{|l|r|}
\hline \multicolumn{2}{|c|}{ Village Income } \\
\hline \multicolumn{1}{|c|}{ Information } & Nominal (IDR) \\
\hline Village Original Income & $164,808,000$ \\
\hline Village Fund & $746,007,000$ \\
\hline Allocation of village funds & $457,630,000$ \\
\hline Tax and Retribution Sharing & $23,549,992$ \\
\hline Provincial Financial Assistance & $75,625,000$ \\
\hline Last year's Silpa & $64,976,692$ \\
\hline Total Village Revenue & $1,532,596,584$ \\
\hline Village Shopping & $510,601,200$ \\
\hline $\begin{array}{l}\text { Field of Implementation of } \\
\text { Village Government }\end{array}$ & $605,616,941$ \\
\hline $\begin{array}{l}\text { Field of Implementation of } \\
\text { Village Development }\end{array}$ & $105,505,003$ \\
\hline $\begin{array}{l}\text { Field of Community } \\
\text { Development }\end{array}$ & $305,573,439$ \\
\hline $\begin{array}{l}\text { Field of Community } \\
\text { Empowerment }\end{array}$ & $1,532,596,584$ \\
\hline Total Village Expenditures
\end{tabular}

Source: Putukrejo Village Government (2019)

From the data above, most of the village expenditure is used for the administration of village government and the implementation of village development. The rest is used for community development and empowerment.

Based on interviews with the chairman of the BUMDes Barokah, the source of capital of the BUMDes Barokah comes mostly from village shopping for community empowerment. In addition, also from the assistance of the district and provincial governments. It can be said that the 2018 Regional Budget allocated for BUMDes is not so large, which is no more than IDR $305,573,439$. Because until 2018, the main focus of the Regional Budget was to develop village infrastructure.

From the capital of BUMDes Barokah which is not so large, it then receives its optimal value from the income received by BUMDes.In 2018, BUMDes Barokah's income has reached around IDR 800,000,000. Then, the income is used for operational costs, expansion of BUMDes, and the remainder goes to PADes. If viewed from an economic standpoint, village funds used for BUMDes Barokah can be used optimally.

Furthermore, BUMDes Barokah is not only optimal in absorbing APBDes to increase PADes, but also, more important in its success to empower the economy of the surrounding community. Especially, with the existence of Sumber Sira Tourism Village Market which is increasingly able to advance the economy of BUMDes Barokah through a creative economy. People, who were initially unemployed at home, could be empowered by starting to pursue crafts, fashion and culinary endeavors 
which were then sale at the Sumber Sira Tourism Village Market

\section{CONCLUSION}

Based on the previous discussion, it can be concluded that BUMDes Barokah currently has four business units that can be used as a medium to empower the community. The four business units are Sumber Sira Tourism Unit, Clean Water and Sanitation Management Unit, Savings and Loans Unit, Business, Creativity, Production and Services, and Agriculture and Fisheries Unit.

The establishment of BUMDes as the beginning of real community empowerment was carried out in Putukrejo Village. Empowerment through BUMDes is carried out not only solely focusing on economic empowerment, but also expected to be able to empower people in politics and culture.

To improve community empowerment, the Putukrejo Village Government observe the potential of the creative economy. This is what underlies the establishment of the Sumber Sira Tourism Village Market. It is expected that the establishment of the tourist village market can further facilitate the community in marketing their creative economic work in the crafts, culinary, and fashion subsectors.

APBDes that have been used for capital of BUMDes can be said to have been used optimally. In terms of economy, BUMDes' income in 2018 is quite high, it is around IDR 800,000,000. More than that, the presence of BUMDes can also increase the economic income of the people who are involved in utilizing BUMDes.

\section{REFERENCES}

[1] N. S. Askandar and J. Susyanti, Introduction of Enterpreneur: Towards Indonesia Independently, Malang: BPFE Unisma, 2017.

[2] L. J. Moleong, Qualitative Research Methods. Bandung:Remaja Rosda Karya, 2012.
[3] G. Kartasasmita, Pemberdayaan Masyarakat: Konsep Pembangunan yang berakar pada Masyarakat. Jakarta: Bappenas, 1996.

[4] A. C. Hamill, C. H. Stein, Culture and Empowerment in the Deaf Community: An Analysis of Internet Weblogs. Journal of Community \& Applied Social Psychology, Vol. 21, 2011, pp. 388406.

[5] A. Ramadana, dkk.. The existence of VillageOwned Enterprises (BUMDes) as Strengthening the Village Economy (Study in the Landungsari Village, Dau District, Malang Regency. Jurnal Administrasi Publik (JAP) 1 (6), 2013, pp. 1068-1076.

[6] A. Herry, Village Readiness Facing the Implementation of the Village Law. Jurnal Ilmiah CIVIS 5 (1), 2015.

[7] V.Q. Chintary and A.W. Lestari, The Role of the Village Government in Managing Village Owned Enterprises (BUMDes). JISIP: Jurnal Ilmu Sosial dan Ilmu Politik 5 (2), 2016, pp. 59-63.

[8] R. Setiawan, 2019, Mendes Wants More Village Fund Allocation for BUMDes. Detik News (Online), (https://finance.detik.com/_) Diakses pada 26 Juli 2019.

[9] H. Herdiansyah, Qualitative Research Methods for Psychology, Jakarta:Salemba Humanika, 2015.

[10] I. A. Olanrewaju, T. O. Jacobs, P. O. Chukwudi. Comparative Assessment Of Rural Development Programs Of Selected Ngos In Plateau State, Northcentral, Nigeria. In Journal rural Social Science. 332 (1), 2017, pp.40-55.

[11] G. Sumodiningrat, Community Empowerment and Social Safety Networks. Jakarta: PT Gramedia Pustaka Utama, 1999.

[12] S. Hendri, et al, The Effect of Human Resources, Facilities and Infrastructure on Village Financial Management Performance in Central Lombok District. Conference on Management and Behavioral Studies, Universitas Tarumanegara, Jakarta, 2016. 